DOI: https://doi.org/10.32782/2410-0927-2020-12-26

УДК $811.112 .2 ’ 374$

Лариса Рись, Максим Якимчук

\title{
ЛЕКСИКОГРАФІЧНА РЕПРЕЗЕНТАЦІЯ КОНЦЕПТУ FRIEDEN В СУЧАСНІЙ НІМЕЦЬКІЙ МОВІ
}

Стаття присвячена дослідженню мовних засобів об'єктивації концепту FRIEDEN та встановленню його основних концептуальних ознак. У роботі систематизовано дані лексикографічних джерел - тлумачних, синонімічних і етимологічних словників та встановлено сукупність мовних засобів, що передають зміст концепту і утворюють його номінативне поле: ключове слово-репрезентант концепту, похідні номінації концепту, спільнокореневі слова, синоніми, словникові дефініції, сталі словосполучення, до складу яких входить ім'я концепту.

Концепт FRIEDEN належить до універсальних концептів, у якому можна виокремити три виміри: він може стосуватися мирного співіснування різних держав, народів (глобальний, міждержавний вимір), гармонійного співіснування з оточенням (соціальний вимір) та внутрішнього спокою і гармонії людини (індивідуальний вимір). На основі етимологічного аналізу визначено етимологічну ознаку концепту FRIEDEN, яка лежить в основі його формування: «стан бережного, доброзичливого ставлення до інших», що трансформувався в сучасних дефініціях у стан гармонії та злагоди із самим собою та оточенням.

На основі аналізу словникових дефініцій імені концепту та дистрибутивного аналізу встановлено основні ознаки концепту FRIEDEN, які відносимо до його понятійного компонента: життя / стан внутрішнього та міждержавного співіснування без насилля та війни; стан гармонії, згоди; стан незворушного, безтурботного спокою; мирний договір, домовленість між сторонами; стан, що характеризується певною тривалістю, територією поширення. Досліджуваний концепт FRIEDEN виявив тісний зв'язок із бінарно протиставленим концептом KRIEG.

Встановлено важливе значення концепту FRIEDEN як для суспільства, так і для окремих особистостей. Мир є великою цінністю, яка, однак, може мати відносний характер, про що свідчать окремі лексичні одиниці, що слугують об'єктивації концепту та мають негативну конотацію, що може бути пов'язаним із місцем цього концепту в ціннісній картині світу та його взаємодією з іншими морально-етичними цінностями народу.

Ключові слова: концепт, концептуальна ознака, об’єктивація концепту, номінативне поле.

Вступ. В епоху інтенсивних міжкультурних контактів посилюється інтерес мовознавців до проблеми взаємозв'язку між мовою і культурою, а також до питання опису етноспецифічної концептосфери в різних лінгвокультурах. Дослідження лінгвоконцептів як «вербалізованих культурних смислів», «семантичних одиниць «мови» культури» [9, с. 125] сприяє пізнанню національної картини світу, встановленню особливостей національного характеру певного етносу, а також значущості окремих концептів для певної лінгвоспільноти.

Звернення до концепту FRIEDEN пояснюється його актуальністю у всі часи та для всіх народів. Категорія Frieden здавна відома філософам, історикам, культурологам, релігієзнавцям. Можливим шляхом до розкриття структурної організації концепту FRIEDEN як одного із найдавніших ментальних утворень людства $\epsilon$ аналіз мовних засобів його представлення, що передбачає як встановлення універсальних, так і національно специфічних компонентів його структури, зумовлених особливостями мови та мислення певного етносу. Безпосереднє дослідження лінгвокультурного концепту МИР було здійснено на матеріалі англійської мови (С. С. Суслова, Ю. В. Зайцева), вивчення національної специфіки бінарних концептів ВІЙНА і МИР представлене на матеріалі англійської, російської та японської мов (О.О.Голубенко). На матеріалі німецької мови концепт FRIEDEN досліджувався лише фрагментарно в поєднанні 3 концептом KRIEG (I. П. Пасєчникова). Окремі наукові розвідки висвітлюють роль концептів FRIEDEN та KRIEG у концептосистемах німецького художнього дискурсу (С. Ф. Соколовська, О. В. Дакаленко). Актуальність цієї наукової розвідки пояснюється як загальним інтересом сучасних лінгвістичних розвідок до вивчення взаємозв'язків мови, свідомості і культури соціуму, так і відсутністю комплексного аналізу концепту FRIEDEN як невід'ємного складника концептуальної та мовної картин світу німецької лінгвоспільноти.

Мета дослідження полягає в характеристиці концепту FRIEDEN крізь призму взаємозв'язку мови та мислення. Досягнення поставленої мети передбачає розв'язання таких завдань: здійснити аналіз мовних засобів об'єктивації концепту FRIEDEN в сучасній німецькій

(C) Рись Л., Якимчук М., 2020 
мові, визначити основні ознаки концепту FRIEDEN на основі аналізу даних лексикографічних джерел.

Методи та методики дослідження. У нашій роботі ми послуговуємось комплексною методикою концептуального аналізу, основною метою якого є реконструкція понять та уявлень носіїв мови про концепт FRIEDEN та встановлення основних когнітивних ознак концепту. Мета й завдання роботи та особливості досліджуваного об'єкта зумовили використання таких методів i прийомів дослідження: етимологічний аналіз для визначення первинного смислу ключового слова та встановлення етимологічної ознаки концепту FRIEDEN, яка лежить в основі його формування; аналіз словникових дефініцій для встановлення основних ознак концепту FRIEDEN; дистрибутивний аналіз для встановлення додаткових ознак концепту шляхом визначення сукупності сполучуваних з ключовою лексемою елементів та аналізу вербалізованих ними смислів.

Результати та дискусії. Концепти $\epsilon$ ідеальними сутностями, які формуються у свідомості людини в результаті пізнавальної діяльності. Лінгвокультурний підхід до розуміння концепту полягає у визнанні культурного концепту базовою одиницею культури, його концентратом [4, с. 116]. Лінгвокультурні концепти - це передусім ментальні сутності, в яких відбивається «дух народу», що і визначає їхню антропоцентричність - орієнтованість на духовність, суб'єктивність і «особисту сферу» носія етнічної свідомості [13, с. 14].

Лінгвокультурний концепт є глобальною, багатовимірною одиницею ментального рівня, для якої, на думку А. М. Приходька, характерні такі ознаки, як цінність (базується на оцінності та актуальності), одночасна належність до мови, свідомості та культури, обмеженість свідомістю носія, умовність і нечіткість (концепт не має чітких границь), складна структурованість, мінливість структури, здатність існувати у вигляді матеріальних мовних засобів [9, с. 4-51].

Структура концепту визначається науковцями по-різному та залежить від змісту досліджуваного концепту. Так, В.І.Карасик виокремлює в лінгвокультурному концепті ціннісний, образний та понятійний компоненти [4, с. 109]. При цьому для лінгвокультурного підходу характерне дослідження ціннісного компонента концепту, оскільки саме цінності народу формують ядро його культури, утворюють ціннісну картину світу, яка є частиною мовної картини світу. Так, на нашу думку, концепт FRIEDEN у всі історичні періоди можна розглядати як беззаперечну цінність, він не втрачає своєї актуальності, оскільки протягом усієї історії свого існування людство веде війни, борючись таким чином за мир та, прагнучи досягнення миру, порушує його.

Г. В. Токарєв говорить про два основні типи змісту в структурі концепту. Перший тип охоплює структуру знань, цінну для всього людства. Цей шар концепту називає науковець «універсальним». Другий шар концепту науковець називає «культурним», оскільки він включає національно-специфічні знання, які продукуються лінгвокультурною спільнотою, поєднаною сукупністю таких ознак, як мова, історія, культура, релігія. Культурний концептуальний шар містить інформацію про соціальну значимість концепту, який у певний історичний період може високо оцінюватися, а в інший - знецінюватися. Це залежить від актуалізації смислів, які входять до складу концепту. Однак ядро концепту залишається відносно стабільним, а пасивний шар зазнає змін [11, с. 15-17].

В. А. Маслова теж виділяє в структурі концепту загальнолюдський, чи універсальний, та національно-культурний компоненти, а поряд 3 тим соціальний, який визначається належністю людини до певного соціального класу; груповий, обумовлений належністю людини до певної вікової чи гендерної групи; індивідуально-особистісний, який формується під впливом особистісних особливостей - освіти, виховання, індивідуального досвіду [5, с. 42]. Загалом дослідники єдині в тому, що ядро концепту утворює його понятійний складник, на який нашаровується те, що привнесене культурою, народним та власним досвідом.

Внутрішній зміст концепту як ментальної сутності «озовнішнюється» мовними знаками, при цьому він може об'єктивуватися цілою низкою вербальних засобів. Сукупність мовних засобів, що передає зміст концепту, утворює його номінативне поле, до якого можуть входити, згідно з 3. Поповою та І. Стерніним, прямі номінації концепту (ключове слово-репрезентант, яке вибирає дослідник як ім'я та назву), похідні номінації концепту, спільнокореневі слова, 
контекстуальні синоніми, оказіональні індивідуально-авторські номінації, сталі словосполучення, фразеологічні одиниці, до складу яких входить ім'я концепту, паремії (приказки, прислів'я, афоризми), вільні словосполучення, які номінують певну ознаку концепту, словникові дефініції, метафоричні номінації, тексти та сукупності текстів [8, с. 38]. Саме встановлення та семантична інтерпретація мовних засобів об'єктивації концепту $є$ основним джерелом отримання достовірних знань структури концепту.

Дослідження етимології лексеми - імені концепту $є$ відправною точкою аналізу концепту, що дає змогу проаналізувати його етимологічний шар та встановити механізм формування. Згідно з Digitales Wörterbuch der deutschen Sprache (DWDS) лексеми Friede/Frieden, які виступають основними репрезентантами концепту FRIEDEN у німецькій мові, означають стан спокою, гармонії, припинення воєнних конфліктів, ще раніше мали значення «захищена, огороджена територія». Ці лексеми походять від старонімецького девербального іменника fridu (VIII ст.), середньонімецького vride, vrit, утвореного від старонімецького кореня frī (frei) за допомогою індоєвропейського суфікса $t u$, який означав «дбайливе ставлення, доброзичливість», що можна вважати етимологічною ознакою концепту FRIEDEN.

Для встановлення основних ознак концепту FRIEDEN проведено аналіз значень ключового слова концепту в шести тлумачних словниках: Online-Wortschatz Informationssystem Deutsch (OWID) [6], Digitales Wörterbuch der deutschen Sprache (DWDS) [3], Duden [1], PONS [7], Wahrig [12] та інтернет-ресурс Wortbedeutung.info (WBI) [14]. Лексикографічні джерела є достовірним джерелом інформації про структуру значення слова, містять найбільш загальні ознаки позначуваного явища, які входять до колективної свідомості лінгвоспільноти, а тому дають змогу встановити основні ознаки концепту, що утворюють понятійний ядерний компонент його структури.

У результаті порівняння словникових дефініцій лексеми Frieden було виділено основні іï значення, які розглядаємо як об’єктивацію основних ознак концепту FRIEDEN:

- життя/ стан внутрішнього та міждержавного співіснування без насилля та війни, протилежність війни: Leben ohne Krieg (OWID), vertraglich geregelter Zustand zwischen den Staaten, der ein Zusammenleben in Ruhe und Sicherheit auf der Grundlage des Völkerrechts gewährleistet (DWDS, PONS), vertraglich gesichertes Miteinander verschiedener Staaten, dass durch Abwesenheit von Gewalt (und speziell von Krieg) gekennzeichnet ist (WBI);

- стан гармонії, згоди: völlig ungestörter, harmonischer Zustand, Eintracht (DWDS), Harmonie (PONS); Zustand ungestörter Ordnung und Harmonie (Wahrig); Zustand harmonischen Miteinanders (WBI);

- стан незворушного, безтурботного спокою: ungestörte Ruhe, Zustand beschaulichheiterer Ruhe (Duden); Zustand, in dem (im gesellschaftlichen bzw. privaten Bereich) Einklang, Ruhe und Ungestörtheit vorherrschen (OWID), heitere Ruhe (DWDS); Ruhe (PONS); Zustand innerer Ruhe und Ausgeglichenheit (Wahrig); Ruhe, beruhigende Stille (WBI);

- мирний договір, укладання миру: ein Abkommen, das es ermöglicht, dass Personen(gruppen) innerhalb eines Staates bzw. innerhalb mehrerer Staaten rechtlich gesichert und ruhig (zusammen)leben können (OWID), vertraglicher Friedensschluss (DWDS), Friedensschluss (Duden, PONS), Friedensschluss, Friedensvertrag (WBI);

- відчуття безпеки, духовного наповнення та благословення: Zustand, in dem spirituelles bzw. religiöses Geborgensein gespürt bzw. gewünscht wird (OWID), Geborgenheit in Gott (Duden); religiöse Erfüllung, Segen (WBI);

- сфера діяльності, пов'язана із запобіганням війнам та збереженням миру: Bereich, der sich mit der Verhütung bzw. Beendigung von Kriegen befasst (OWID);

- історичне: гарантований захист людини та іï власності (obrigkeitlich garantierter Schutz der Person und ihres Eigentums) (DWDS). 
Основні ознаки концепту FRIEDEN

\begin{tabular}{|l|c|c|c|c|c|c|}
\hline Ознака/словник & OWID & DWDS & Duden & PONS & WBI & Wahrig \\
\hline Leben ohne Krieg & + & + & + & + & + & + \\
\hline $\begin{array}{l}\text { Abkommen, vertraglicher } \\
\text { Friedensschluss }\end{array}$ & + & + & + & + & + & + \\
\hline Zustand der Eintracht, der Harmonie & + & + & + & + & + & + \\
\hline Ruhe und Ungestörtheit & + & + & + & + & + & + \\
\hline Geborgenheit in Gott & + & + & + & - & + & - \\
\hline
\end{tabular}

Як бачимо $з$ таблиці 1, до основних ознак концепту можна віднести «життя без війни», «стан згоди, гармонії», «стан спокою» та ознаку «укладання миру, мирний договір», які представлені у всіх проаналізованих джерелах. Хочемо зазначити, що всі словники позначають мир як стан, який регулюється певними домовленостями, мирними договорами, через що сама лексема набула значення «мирний договір». Це демонструють такі приклади: den Frieden schließen, unterzeichnen, verkünden, über den Frieden verhandeln, der Westfälische Frieden von 1648.

У чотирьох словниках зафіксовано значення лексеми Frieden, пов'язане з релігією: «відчуття безпеки, захищеності, духовного наповнення та благословення», що демонструють також приклади: Friede sei mit euch! ruhe in Frieden! in den ewigen Frieden eingehen. Лише один із словників OWID виокремлює значення «сфери діяльності, пов'язаної із запобіганням війнам та збереженням миру», та в корпусі DWDS зафіксоване історичне застаріле значення «гарантований захист людини та іï власності», а це свідчить про те, що ці ознаки не $\epsilon$ актуальними та знаходяться на периферії смислової структури концепту.

Аналіз сполучуваності лексеми Frieden (iі дистрибуціï) дозволяє виокремити й інші, додаткові ознаки концепту. Так, поєднання слова Frieden 3 деякими прикметниками свідчить про бачення миру як стану, що характеризується певною тривалістю: ein beständiger, langer, dauerhafter, ewiger Frieden; відповідно цей стан може бути порушеним: Frieden brechen, Frieden stören. Концепт FRIEDEN є позитивно маркованим: ein guter, gerechter, wahrer Frieden; ein ehrenvoller, günstiger Frieden, однак виявлені композити, у яких мир отримує негативну характеристику через семантику першого складника композита: Schandfrieden (ганебний мир), Scheinfrieden (удаваний мир). Ці композити описують умови, на яких здійснюються домовленості про мир та які можуть негативно сприйматися однією із сторін. Негативна конотація властива і сталому виразу Friede, Freude, Eierkuchen, який слугує для позначення стану відновленої, однак сумнівної гармонії.

Як ми зазначали, до засобів об’єктивації концепту, які входять до його номінативного поля, належать слова, спільнокореневі з основним мовним репрезентантом концепту. Так, у німецькій мові існує багато складних іменників із лексемою Frieden як основного другого складника, що слугують уточненню, характеристиці певних умов чи ознак миру/ мирної домовленості. Композит може передавати спосіб укладання миру: Diktatfrieden, Kompromissfrieden, Verhandlungsfrieden; називати сторони, які укладають мирні домовленості: Koalitionsfrieden, Parteifrieden, Separatfrieden, Völkerfrieden; територію поширення: Weltfrieden, Landfrieden; причину (війни та відповідно потім встановленого миру): Religionsfrieden; оцінні характеристики: Schandfrieden, Scheinfrieden. Композити, які містять Frieden як перший складник, слугують характеристиці інших понять, пов'язаних 3 концептом FRIEDEN: Friedensangebot, Friedensappell, Friedensbedingung, Friedensbotschaft, Friedensengel, Friedensfahne, Friedensfreund, Friedenliebe, Friedenspolitik, Friedenstaube, Friedenssymbol usw.

Серед прикметників із спільним коренем спостерігаємо в основному прикметники, що позначають наявність ознаки «мир», «спокій»: friedensbereit, friedfertig, friedlich, friedvoll та один прикметник із антонімічним значенням: friedlos. Дієприкметники реалізують значення, пов'язане із певною дією: friedensgefährdend (той, що загрожує миру), friedliebend (миролюбний). 
Спільнокореневі дієслова, виявлені у словнику Duden, frieden, befrieden, einfrieden, umfrieden походять від того ж староверхньонімецького кореня, що й лексема Frieden та зберегли значення «загороджувати, оточувати парканом», яке раніше було властиве і слову Frieden. Лише дієслово befrieden співвідноситься із актуальним значенням іменника Frieden та має значення «примиряти».

Важливе місце серед мовних засобів об'єктивації концепту посідають синоніми. Проаналізувавши інтернет-ресурс Synonyme.woxikon [10], який пропонує 187 синонімів у 14 семантичних групах та дані словника синонімів Duden [2], ми виокремили чотири основні синонімічні групи до ключового слова Frieden, об'єднані спільним смисловим компонентом:

1) значення життя без війни: Friedenszeit, Friedenszustand, Kriegsende, Waffenstillstand, Kampfende, Disengagement, Waffenruhe;

2) значення мирного договору: Friedensschluss, Friedensvertrag, Versöhnung, Verständigung, Kompromiss;

3) значення згоди, гармонії: Einigkeit, Einmütigkeit, Eintracht, Einvernehmen, Harmonie, Übereinstimmung, Einklang, Ausgleich, Gleichklang;

4) значення спокою: Ruhe, Stille, Entspannung, Muße, Seelenruhe, Geborgenheit, Ausgeglichenheit, Gelassenheit, Ungestörtheit.

Аналіз дефініцій ключового слова виявив тісний зв'язок концепту FRIEDEN з бінарним концептом KRIEG, адже всі словники зазначають, що мир є існуванням без війни, а в словнику PONS перша семантизація лексеми Frieden $є$ антонімічною: «протилежність війни». У такому способі семантизації виявляється властивість концепту, яку відзначає А. М. Приходько, «об'єктивуватися через рядопокладені одиниці» [9, с. 101]. У синонімічних рядах теж спостерігаємо поняття, що мають стосунок до війни: Kriegsende, Waffenruhe, Waffenstillstand. Саме тому вважаємо, що антоніми теж є важливим способом об'єктивації концепту, адже протилежності можна пізнати лише в їхньому поєднанні.

На основі аналізу лексикографічних джерел та виокремлених з них мовних засобів вербалізації концепту FRIEDEN змодельовано номінативне поле, яке представляє найбільш поширені мовні засоби, що використовуються для номінації самого концепту та його основних ознак.

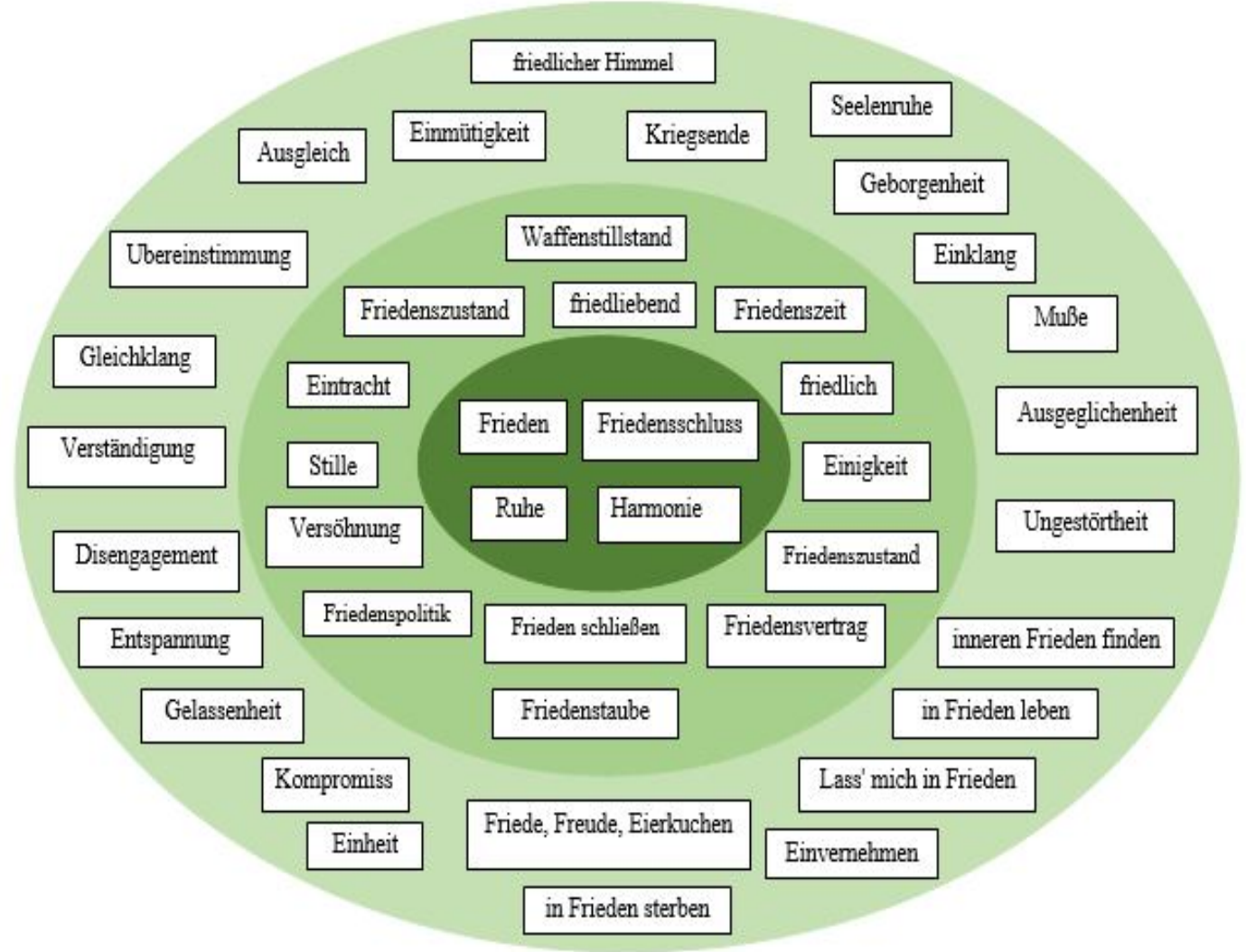

Рис. 1. Номінативне поле конщепту FRIEDEN 
Висновки. Концепт FRIEDEN належить до універсальних концептів, у якому можна виокремити три виміри, залежно від чого він актуалізує певні свої ознаки. Так, концепт FRIEDEN може стосуватися мирного співіснування різних держав, народів (глобальний, міждержавний вимір), гармонійного співіснування 3 оточенням (соціальний вимір) та внутрішнього спокою і гармонії (індивідуальний вимір). Основний репрезентант концепту FRIEDEN у німецькій мові походить від назви стану дбайливого, доброзичливого ставлення до інших, що трансформувалося у сучасних дефініціях в стан гармонії та злагоди із самим собою та оточуюченням. Словотвірні конструкції зі словом Frieden, сталі вирази та вживані сполучення слів із ключовою лексемою характеризують мир також як стан, що виникає на основі певних домовленостей між сторонами, характеризується певною тривалістю, територією поширення, має позитивні, а інколи і негативні оцінні характеристики. Встановлення за окремими мовними структурами негативної конотації пов'язане з місцем цього концепту в ціннісній картині світу та його взаємодією з іншими морально-етичними цінностями народу. Перспективою подальших розвідок є проведення психологічного асоціативного експерименту та детальне дослідження представлення концепту FRIEDEN в індивідуальній свідомості представників німецької лінгвоспільноти.

\section{References}

1. DUDEN-Onlinewörterbuch. https://www.duden.de/suchen/dudenonline/Frieden

2. DUDEN. Das Synonymwörterbuch. 2007. 4. Auflage. Bd. 8.. Mannheim: Dudenverlag

3. DWDS - Digitales Wörterbuch der deutschen Sprache ma Deutsches Universalwörterbuch. https://www.dwds.de/wb/Frieden

4. Karasik, Vladimir. 2004. Yasykovoi krug: lichnost, konzepty, diskurs. Moskwa: Gnozis

5. Maslova, Valentina. 2004. Kognitivnaya lingvistika : uchebnoye posobiye. Minsk: TetraSistems.

6. Online-Wortschatz Informationssystem Deutsch (OWID). https://www.owid.de/artikel/ 401460?module $=$ ctx.all\&pos $=12$ )

7. PONS Bedeutungswörterbuch. https://ru.pons.com/

8. Popova, Zinaida and Iosif Sternin. 2007. Kognitivnaya lingvistika. Moskva: Vostok-Zapad.

9. Prykhodko, Anatoliy. 2008. Konzepty i konzeptosystemy v kohnityvno-dyskursivniy paradyhmi linhvistyky. Zaporizhzhya: Premier

10. Synonyme. Woxikon. https://synonyme.woxikon.de/synonyme/friede.php.

11. Tokarev, Grigoriy. 2009. Lingvokulturologiya. Tula.

12. Wahrig, Gerhard. 1991. Deutsches Wörterbuch. Bertelsmann Lexikon Verlag.

13. Vorkachev, Sergei. 2003. Sopostavitelnaya etnosemantika teleonomnykh konzeptov «lubov» $i$ «schastye» (russko-angliyskiye paralelli). Volgograd: Peremena.

14. Wortbedeutung.info. https://www.wortbedeutung.info/frieden

Рысь Лариса, Якимчук Максим. Лексикографическая репрезентация концепта FRIEDEN в современном немецком языке. Статья посвящена исследованию языковых средств объективации концепта FRIEDEN и установлению его основных концептуальных признаков. В работе систематизированы данные лексикографических источников - толковых, синонимических и этимологических словарей и установлена совокупность языковых средств, которые передают содержание концепта и образуют его номинативное поле: ключевое слово-репрезентант концепта, производные номинации концепта, синонимы, устойчивые словосочетания, в состав которых входит имя концепта, словарные дефиниции.

Концепт FRIEDEN принадлежит к универсальным концептам. В нем можно выделить три измерения: он может обозначать мирное сосуществование различных государств, народов (глобальное, межгосударственное измерение), гармоничное сосуществование с окружающими (социальное измерение) и внутренний покой и гармонию человека с самим собой (индивидуальное измерение). На основе этимологического анализа определен этимологический признак концепта FRIEDEN, который лежит в основе его формирования: «состояние бережного, доброжелательного отношения к другим», что трансформировалось в современных дефинициях в состояние гармонии и согласия с самим собой и окружающими.

На основе анализа словарных дефиниций имени концепта и дистрибутивного анализа установлены основные признаки концепта FRIEDEN, которые относим к его понятийному компоненту: жизнь / состояние внутреннего и межгосударственного сосуществования без насилия и войны; состояние гармонии, согласия; состояние невозмутимого, безмятежного покоя; мирный договор, договоренность между сторонами. Исследуемый концепт FRIEDEN обнаружил тесную связь с бинарно противопоставленным концептом KRIEG.

Установлено большое значение концепта FRIEDEN как для общества, так и для отдельных личностей. Мир является большой ценностью, которая может иметь относительный характер, о чем свидетельствуют отдельные лексические единицы, которые служат объективации концепта и имеют отрицательную коннотацию, что может 
быть связано с местом этого концепта в ценностной картине мира и его взаимодействием с другими моральноэтическими ценностями народа.

Ключевые слова: концепт, концептуальный признак, объективация концепта, номинативное поле.

Rys Larysa, Yakymchuk Maksym. Lexicographic Representation of the Concept FRIEDEN in Modern German. The article deals with the analysis of the concept FRIEDEN and linguistic means of its verbalization in modern German. The material of lexicographic sources - explanatory, etymological and synonym dictionaries is systematized. Language means that characterize the concept and its features such as a main word that represents the concept in the language, derivatives of the concept's nominations, synonyms, stable phrases, which include the concept's name, dictionary definitions are established and the nominative field oh the concept FRIEDEN is modeled.

The concept FRIEDEN belongs to universal concepts. Three its dimensions can be distinguished: it can denote the peaceful coexistence of various states (global, interstate dimension), harmonious coexistence with other people (social dimension) and inner peace and harmony of a person with himself (individual dimension). Based on the etymological analysis, the etymological feature of the concept FRIEDEN which underlies its formation is determined: "a state of protection, of caring, friendly attitude towards others", which has transformed in modern definitions into a state of harmony with oneself and others.

As a content of concepts is close to the content of the concept main word's dictionary definition, lexicographic analysis and distributional analysis of the concept name are carried out, and the main features of the concept FRIEDEN which are related to its conceptual component are established. The basic conceptual features are considered to be: life / state of internal and interstate coexistence without war or other hostilities; a state of harmony; a state of serenity; peace treaty, agreement between the parties; a condition characterized by a certain duration and territory of distribution. A close connection between the concept FRIEDEN and the binary opposed concept KRIEG is revealed.

The great importance of the concept FRIEDEN both for society and for individuals is established. The peace is a great value, which can be of a relative nature, as evidenced by individual lexical units that serve to verbalize the concept, and have a negative connotation, which may be related to the place of this concept in the value picture of the world and its interaction with other moral and ethical values of the people.

Keywords: concept, conceptual feature, verbalizing of the concept, nominative field.

DOI: https://doi.org/10.32782/2410-0927-2020-12-27

УДК 811.133.1'42:82-3(045)

Руслана Савчук

\section{ФРАНЦУЗЬКИЙ ОНІРИЧНИЙ НАРАТИВ: ДОСВІД ЛІНГВОСЕМІОТИЧНОГО АНАЛІЗУ (НА МАТЕРІАЛІ РОМАНУ Ж. ДЕ НЕРВАЛЯ “AURÉLIA OU LE RÊVE ET LA VIE”)}

У статті представлені та проаналізовані найбільш показові лінгвонаративні і лінгвокогнітивні механізми конструювання оніричної оповіді, віднайдені у французькому художньому текстотворенні ХІХ століття. 3’ясування текстотвірного потенціалу “змінених станів свідомості” як знаково-мовних структур відображення наративних стратегій у французьких прозових творах дає змогу простежити динаміку наративного мислення письменників як представників певної історико-культурної епохи. Французькі прозові твори XIX століття є тими зразками художнього мислення письменників, які відображають суспільні настрої в кожну історичну добу, а тому аналіз їх мовотворчих потенцій $є$ необхідним для реконструкції механізмів трансформації когнітивних структур у знакові мовні форми. 3 метою визначення прикметних тенденцій у формуванні та форматуванні оніричного наративу означеного вище проміжку часу з'ясовані головні закономірності породження та розгортання оповіді в аспекті образно-стилістичної фігуративності в плані семіозису наративних прийомів, технік або тактик французького художнього текстотворення. Із позицій лінгвонаратології, лінгвосеміотики, а також із залученням здобутків семантики можливих світів і стилістики художнього мовлення з'ясовано, що французьке художнє текстотворення XIX століття відзначається побудовою та форматуванням оніричної оповідної реальності, яка характеризується множинністю, метафоричністю, фантастичністю та емоційно-смисловою значущістю оповідного зображення. 3 погляду лінгвосеміотичного підходу стрижневою ознакою французького художнього наративу XIX ст. $\epsilon$ “"змінені стани свідомості” письменника, які виступають референтами відображення та конструювання оніричної оповідної реальності. У пропонованій статті з'ясовано, що французький оніричний наратив вибудувано в дискурсі сновидінь $\mathrm{i}$ сонних візій гомодієгетичного оповідача, що співвідноситься 3 мовною особистістю самого французького письменника. Установлено, що в розглядуваному романі “Aurélia ou le rêve et la vie” текстуальними засобами творення квазіреальності виступають оніричні лексеми та численні засоби образно-стилістичної фігуративності із семою ‘уявне / неможливе'.

Ключові слова: оніричний наратив, онірична оповідна реальність, лінгвосеміотика, французьке художнє текстотворення, змінені стани свідомості.

(C) Савчук P., 2020 